\title{
microRNA-605 Directly Targets SOX9 to Alleviate the Aggressive Phenotypes of Glioblastoma Multiforme Cell Lines by Deactivating the PI3K/Akt Pathway [Retraction]
}

\author{
Jia J, Wang J, Yin M, Liu Y. Onco Targets Ther. \\ 2019;12:5437-5448.
}

The Editor and Publisher of OncoTargets and Therapy wish to retract the published article. Concerns were raised over alleged image duplication in Figure 7B with a similar image from an unrelated study, specifically:

- Figure 7B, Agomir-605 appears to have been duplicated with a similar image in Figure 9A, miR-944 mimics from Lv et al, 2019 (https://doi.org/10.2147/ CMAR.S199818).
The authors responded to our queries but were unable to provide an explanation for the alleged image duplication and could not provide the original raw data for their study and have therefore agreed to retract the article.

Our decision-making was informed by our policy on publishing ethics and integrity and the COPE guidelines on retraction.

The retracted article will remain online to maintain the scholarly record, but it will be digitally watermarked on each page as "Retracted".

\section{Publish your work in this journal}

OncoTargets and Therapy is an international, peer-reviewed, open access journal focusing on the pathological basis of all cancers, potential targets for therapy and treatment protocols employed to improve the management of cancer patients. The journal also focuses on the impact of management programs and new therapeutic agents and protocols on patient perspectives such as quality of life, adherence and satisfaction. The manuscript management system is completely online and includes a very quick and fair peer-review system, which is all easy to use. Visit http://www.dovepress.com/ testimonials.php to read real quotes from published authors. 